\title{
Pengembangan Lembar Timbang Terima Dokter di Unit Gawat Darurat untuk Membangun Komunikasi Efektif
}

\section{Developing Physician Handover Form at Emergency Department to Support Effective Communication}

\author{
Nofita Dwi $H^{1}$, Asih Tri $R^{2}$, Satra Wiyanto ${ }^{3}$ \\ ${ }^{1}$ Rumah Sakit Umum Mitra Delima Malang \\ ${ }^{2}$ Dinas Kesehatan Kota Malang \\ ${ }^{3}$ Rumah Sakit Islam Aisyah Malang
}

\begin{abstract}
ABSTRAK
Komunikasi pada masa transisi pelayanan di rumah sakit merupakan titik kritis dalam manajemen keselamatan pasien. Unit Gawat Darurat rumah sakit merupakan ujung tombak dan pintu masuk pelayanan dengan intensitas pelayanan yang tinggi, sehingga mempunyai potensi insiden yang tinggi pula. Penelitian ini dilakukan untuk mengeksplorasi proses timbang terima untuk mengembangkan model form timbang terima sehingga meningkatkan kualitas komunikasi. Penelitian ini menggunakan metode kualitatif dengan cara melakukan observasi, membagikan kuisioner, dan diskusi dengan subjek penelitian. Observasi dilakukan pada tiga setting transisi pelayanan yaitu UGD, Kamar Bersalin dan Rawat Inap. Wawancara dan diskusi dilakukan responden Dokter UGD. Hasil observasi menunjukkan proses timbang terima yang belum baku terutama komponen informasi yang disampaikan sehingga mengakibatkan potensi insiden keselamatan pasien. Hasil diskusi kelompok mengidentifikasi komponen atau aspek penting yang harus dikomunikasikan pada proses timbang terima yang meliputi laporan kondisi dan perkembangan keseluruhan pasien, peralatan penunjang (inventaris peralatan) termasuk stok obat, serta kondisi pada unit terkait yang juga merupakan bagian dari tanggung jawab Dokter Jaga IGD. Format timbang terima yang dikembangkan merupakan timbang terima pada tingkat unit, sesuai dengan tanggungjawab Dokter Jaga.
\end{abstract}

Kata Kunci: Keselamatan pasien, komunikasi, timbang terima

\begin{abstract}
Communication on the transition services in hospital is a critical point in the patient safety management. Emergency Unit of a hospital is the spearhead and the service entrance with high intensity of service, so that it has high potential incidents as well. This study was conducted to explore the handover process to develop handover form models to improve the communication quality. This study used a qualitative method by means of observation, questionnaires distribution, and discussion with research subjects. Observations were conducted at three transitional care settings namely Emergency Room, Delivery Room and Inpatient Unit. Interviews and discussions were conducted with emergency physician respondents. Observation results indicate that the handover processes were not standard especially on the information component conveyed thus resulting in potential patient safety incidents. The group discussion results identify components or critical aspects that must be communicated to the handover process that includes the report on patient's overall condition and development, supporting equipment (inventory) including drug stocks, as well as conditions related to the units which are also part of IGD attending physician's responsibility. The developed handover format is a form at the unit level, according to the physician's responsibility.
\end{abstract}

Keywords: Communication, handover, patient safety

Jurnal Kedokteran Brawijaya, Vol. 28, Suplemen No. 1, 2014: Nofita Dwi H. Rumah Sakit Umum Mitra Delima Malang, Jl. Raya Krebet Blambangan, Bululawang, Malang 65171 Tel.(0341)805183 Email:nofitayudha@gmail.com 


\section{PENDAHULUAN}

Pelayanan rumah sakit harus mampu memberikan pelayanan yang memuaskan pasien dan menjamin keselamatan pasien (1). Tercapainya keselamatan pasien menjadi salah satu indikator tercapainya mutu pelayanan kesehatan dan persyaratan dalam akreditasi (2). Sampai saat ini pencapaian keselamatan pasien dirasakan masih belum optimal. Hal tersebut tampak dari masih tingginya angka kesalahan medis (medical errors) di berbagai fasilitas kesehatan. Di RSUD Raden Mataher Jambi, penerapan keselamatn pasien oleh perawat pelaksana hanya mencapai angka 35,7\% (3). Hampir 1,3 juta kasus kesalahan medis terjadi setiap tahunnya, dengan 48.000 sampai 98.000 dari kasus tersebut mengakibatkan kematian pasien (4).Banyak penelitian yang mencoba mencari penyebab kegagalan penerapan budaya keselamatan pasien ini. Berdasarkan hasil laporan JCl, komunikasi menjadi salah satu penyebab utama terjadinya sentinel event yang terjadi di USA pada tahun 1992 sampai dengan 2006. Di Australia, sebanyak 25.000 sampai dengan 30.000 kejadian sentinel event yang seharusnya dapat dicegah, $11 \%$ diantaranya disebabkan karena kegagalan komunikasi. Hanya $6 \%$ kejadian sentinel event yang disebabkan karena keterampilan tenaga medis (5).

Komunikasi antar profesi di rumah sakit terjadi sepanjang waktu perawatan pasien di rumah sakit. Komunikasi bertujuan untuk menjaga kelangsungan proses perawatan pada pasien. Salah satu komunikasi antar profesi di rumah sakit terjadi pada saat timbang terima pasien. Timbang terima pasien adalah bentuk transfer tanggung jawab perawatan dan tanggung jawab medis pasien dari satu tenaga kesehatan ke tenaga kesehatan lainnya (5). Komunikasi selama proses timbang terima pasien merupakan periode kritis terhadap kontinuitas dan keberhasilan perawatan pasien (6).

Unit gawat darurat (UGD) merupakan unit pada rumah sakit dengan intensitas yang tinggi dan memberikan pelayanan selama 24 jam dalam tiga periode (shift). Pada kondisi tersebut komunikasi pada proses timbang terima merupakan faktor penting untuk menjamin keberlanjutan pelayanan dan keselamatan pasien. Keberhasilan timbang terima pasien saat pergantian jam dinas dokter di UGD dipengaruhi oleh berbagai faktor, seperti: komunikasi antar dokter yang dapat dibentuk melalui pelatihan formal tentang komunikasi, dan adanya lembar timbang terima yang berisi daftar informasi yang harus disampaikan pada proses timbang terima (7). Lembar timbang terima berfungsi untuk pedoman sekaligus bukti rekaman proses timbang terima yang dapat dijadikan sebagai sumber dokumen evaluasiBelum adanya lembar timbang terima yang digunakan saat pergantian jam dinas dokter di UGD RSIA Malang dapat menyebabkan terhambatnya kontinuitas perawatan pasien. Penelitian ini dilakukan untuk mengeksplorasi proses timbang terima sebagai dasar dalam mengembangkan lembar timbang terima.

\section{METODE}

Penelitian ini dilakukan dengan observasi proses timbang terima, membagikan kuisioner kepada 6 dokter full time yang bertugas di UGD RSIA Malang dan diskusi kelompok dengan dengan 6 dokter full time yang bertugas di UGD RSIA Malang. Penelitian ini dilakukan mulai 8 Oktober 2013 sampai dengan 20 November 2013. Proses observasi timbang terima dilakukan dengan tujuan mengamati proses timbang terima yang terjadi saat ini serta mencatat informasi yang disampaikan dan informasi yang sering tidak disampaikan pada proses timbang terima yang membuat terhambatnya kontinyuitas pelayanan pasien. Observasi dilakukan pada setiap pergantian jam dinas dokter di UGD RSIA Malang, yaitu pada pukul 07.00, 14.00, dan 21.00. Pengamatan dilakukan 1 jam sebelum waktu timbang terima, pada saat timbang terima, dan 1 jam setelah waktu timbang terima. Observasi dilakukan sebanyak 9 kali, yaitu 3 kali pada timbang terima pukul 07.00, 3 kali pada timbang terima pukul 14.00, dan 3 kali pada timbang terima pukul 21.00. Masing-masing observasi dilakukan pada hari yang berbeda untuk mendapatkan gambaran timbang terima dari 6 dokter full time yang bertugas di UGD RSIA Malang.

Kuisioner disusun dengan menggunakan pertanyaan terbuka yang bertujuan untuk mengetahui pengetahuan dokter tentang timbang terima, terkait manfaat, cara melakukan timbang terima, dan dampak timbang terima terhadap kontinuitas pelayanan pasien. Diskusi kelompok dilakukan dengan tujuan mendapatkan kesepakatan tentang informasi apa saja yang menurut dokter full time yang bertugas di UGD RSIA Malang penting untuk disampaikan pada proses timbang terima.

\section{HASIL}

\section{Gambaran Proses Timbang Terima}

Timbang terima saat pergantian jam dinas dokter di UGD RSIA Malang berlangsung setiap pukul 07.00, 14.00, dan 21.00. Komunikasi dalam proses timbang terima dilakukan secara langsung dari dokter yang selesai dinas kepada dokter yang akan dinas. Belum ada lembar timbang terima yang khusus digunakan dalam proses tersebut, sehingga terjadi ketidakseragaman informasi yang disampaikan pada saat timbang terima.

Informasi yang selalu disampaikan pada timbang terima adalah keluhan utama pasien datang ke UGD RSIA Malang, hasil pemeriksaan dan terapi yang sudah diberikan. Informasi yang seringkali tidak disampaikan pada saat timbang terima pasien adalah: identitas pasien (nama pasien), rencana pelayanan selanjutnya dari pasien yang ada di UGD, rencana penerimaan rujukan dari luar, dan kondisi sarana dan prasarana di UGD. Informasi yang tidak disampaikan saat timbang terima tersebut menyebabkan kebingungan bagi dokter yang bertugas selanjutnya. Tidak jarang dokter harus menghubungi kembali dokter yang lepas dinas untuk memperjelas pemeriksaan dan rencana tindakan terhadap pasien tersebut. Hal tersebut akan memperlama waktu penanganan pasien di UGD. Tidak ada perbedaan proses timbang terima saat jam dinas pagi, sore, maupun malam.

\section{Pemahaman Dokter tentang Timbang Terima}

Hasil penelitian dari 6 kuisioner disimpulkan bahwa sebagian besar dokter full time yang bertugas di UGD RSIA Malang memahami bahwa timbang terima merupakan proses transfer tanggungjawab perawatan pasien dari dokter yang lepas dinas ke dokter yang akan dinas. Meskipun demikiansemua dokter full time yang bertugas di UGD RSIA Malang belum mengerti bahwa salah syarat keberhasilan timbang terima adalah komunikasi antar dokter. Dokter juga tidak memahami bahwa proses komunikasi memerlukan ketrampilan tersendiri yang dapat dibentuk melalui pelatihan formal tentang 
komunikasi. Pentingnya lembar timbang terima yang berisi daftar informasi yang harus disampaikan pada proses timbang terima juga belum dipahami. Hasil juga menunjukkan sebagian besar dokter full time yang bertugas di UGD RSIA Malang sudah mengerti manfaat timbang terima pasien yaitu tercapainya kontinuitas pelayanan pasien, dankepuasan pasien. Bahaya yang kemungkinan muncul jika proses timbang terima tidak berjalan dengan baik diantaranya pengulangan pemeriksaan pasien, penundaan disposisi pasien, dan kesalahan terapi.

\section{Informasi pada Proses Timbang Terima}

Hasil diskusi dengan kelompok dokter full time yang bertugas di UGD RSIA Malang menunjukkan bahwa harus ada keseragaman informasi yang disampaikan dalam proses timbang terima saat pergantian jam dinas dokter di UGD RSIA Malang, sehingga tercapai kontinuitas perawatan pasien dan mempercepat waktu penanganan pasien di UGD. Informasi yang harus disampaikan dalam proses timbang terima selanjutnya dituangkan dalam bentuk lembar timbang terima. Terdapat 2 kelompok informasi yang harus tertulis dalam lembar timbang terima yaitu informasi yang menggambarkan suasana internal UGD dan eksternal UGD. Informasi yang dapat menggambarkan suasana internal UGD selama jam dinas dokter yang akan lepas dinas yang perlu disampaikan dalam proses timbang terima adalah: jumlah pasien yang sudah keluar UGD maupun yang masih tersisa di UGD, kondisi sarana dan prasarana UGD, serta rencana kegiatan di UGD seperti rencana penerimaan rujukan dari luar RSIA Malang. Informasi yang dapat menggambarkan suasana eksternal UGD yang berpengaruh terhadap pelayanan pasien di UGD adalah jumlah tempat tidur kosong di ruang rawat inap, informasi tentang laboratorium, radiologi, dan penunjang lainnya, serta jadwal dokter spesialis yang bertugas di ruang rawat inap pada hari itu (Gambar 1).

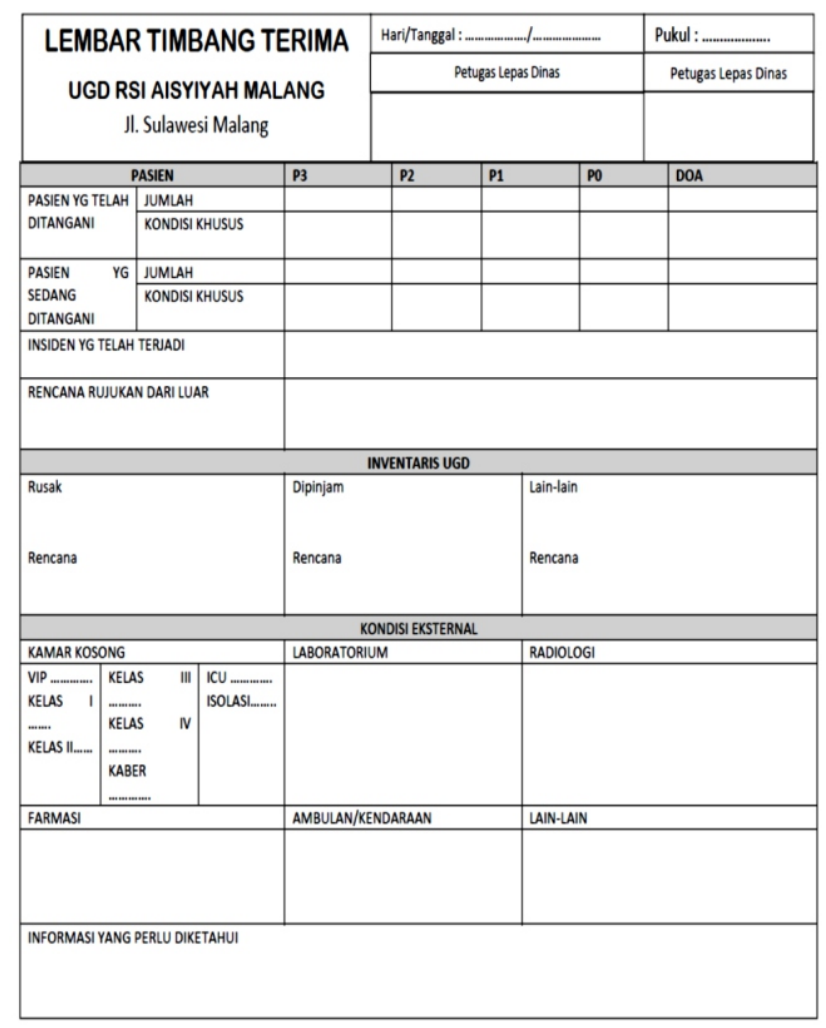

\section{DISKUSI}

Komunikasi merupakan suatu proses penyampaian pesan yang dapat berupa pesan informasi, ide, emosi, keterampilan dan sebagainya melalui simbol atau lambang yang dapat menimbulkan efek berupa tingkah laku yang dilakukan dengan media-media tertentu. Komunikasi meliputi lima unsur sebagai jawaban dari pertanyaan yang diajukan itu, yakni komunikator, pesan, media, komunikan, efek (8). Salah satu komunikasi yang terjadi di rumah sakit adalah komunikasi antar profesi kesehatan. Komunikasi antar profesi kesehatan di rumah sakit dapat berlangsung dalam beraneka ragam bentuk, baik antar individu maupun antar departemen. Komunikasi bertujuan untuk menjaga kelangsungan proses perawatan pada pasien. Salah satu komunikasi antar profesi di rumah sakit terjadi pada saat timbang terima pasien. Timbang terima pasien didefinisikan sebagai bentuk transfer tanggung jawab perawatan dan tanggung jawab medis pasien dari satu tenaga kesehatan ke tenaga kesehatan lainnya (5). Tujuan dari timbang terima pasien adalah terjadikomunikasi yang akuratdan dapat diandalkan terkait informasi spesifik pasien, sehinggadapat memastikan terbentuknyalingkungankerja yang amandan efektif secara terus menerus demi tercapainya kontinyuitas perawatan pasien (9). Timbang terima pasien dapat terjadi pada saat pergantian jam dinas dokter di UGD. Keberhasilan proses timbang terima pasien saat terjadi pergantian jam dinas dokter di UGD dipengaruhi oleh berbagai faktor, seperti: komunikasi antar dokter yang dapat dibentuk melalui pelatihan formal tentang komunikasi efektif, dan adanya struktur yang digunakan dalam proses timbang terima pasien (7).

Jam dinas dokter di UGD RSIA Malang dibagi menjadi 3 waktu dalam satu harinya, yaitu pagi (07.00-14.00), sore (14.00-21.00), dan malam (21.00-07.00). Setiap pergantian jam dinas dokter akan terjadi proses timbang terima. Dari hasil penelitian, tampak bahwa proses timbang terima yang dilakukan oleh dokter di UGD RSIA Malang masih belum efektif. Hal tersebut tampak dengan masih seringnya dokter UGD yang dinas menelpon kembali dokter UGD yang lepas dinas terkait rencana tindakan terhadap pasien di UGD. Komunikasi yang buruk dapat menjadi penyebab terjadinya permasalahan serius di sebuah rumah sakit, seperti terjadinya insiden keselamatan pasien dan kualitas layanan kesehatan yang buruk (10). Komunikasi yang buruk dalam proses timbang terima di UGD dapat membuat waktu tunggu penanganan pasien di UGD menjadi lebih lama (7). Waktu tunggu yang terlalu lama tersebut dapat menurunkan kepuasan pasien di UGD RSIA Malang.

Salah satu faktor penyebab ketidakberhasilan timbang terima di UGD RSIA Malang adalah belum adanya lembar timbang terima yang berisi informasi-informasi yang harus disampaikan dalam proses timbang terima. Dari hasil observasi timbang terima saat pergantian jam dinas dokter di UGD RSIA Malang dan kuisioner yang disebarkan kepada dokter full time yang bertugas di UGD RSIA Malang ketidakseragaman informasi yang disampaikan saat timbang terima dapat menyebabkan terhambatnya kontinyuitas pelayanan pasien di UGD. Dari hasil diskusi dengan kelompok dokter full time yang bertugas di UGD RSIA Malang disepakati bahwa harus ada keseragaman informasi yang disampaikan dalam proses timbang terima saat pergantian jam dinas dokter di UGD RSIA Malang, sehingga tercapai kontinuitas pelayanan pasien dan 
mempercepat waktu penanganan pasien di UGD. Informasi tersebut dituangkan dalam lembar timbang terima. Lembar timbang terima tersebut bukan hanya berisi informasi tentang pasien yang sedang berada di UGD, tetapi mencakup seluruh informasi yang mendukung kontinyuitas perawatan pasien di UGD. Terdapat 2 kelompok informasi yang dapat mendukung kontinyuitas perawatan pasien di UGD, yaitu informasi

\section{DAFTAR PUSTAKA}

1. Tjiptono F, Chandra G, dan Adriana D. Pemasaran Strategik. Edisi 2. Yogyakarta: Andi; 2008.

2. Soepojo P, Koentjoro T, dan Utarini A. Benchmarking Sistem Akreditasi Rumah Sakit di Indonesia dan Australia (Benchmarking of Hospital Accreditation System in Indonesia and Australia). Jurnal Manajemen Pelayanan Kesehatan. 2002; 5.

3. Dewi M. Pengaruh Pelatihan Timbang Terima Pasien terhadap Penerapan Keselamatan Pasien oleh Perawat Pelaksana di RSUD Raden Mattaher Jambi. Jurnal Health and Sport. 2012; 5(3):646-655.

4. Keller S. Effects of Extended Work Shifts and Shift Work on Patient Safety, Productivity, and Employee Health. American Association of Occupational Health Nursing Journal. 2009; 57(12): 497-502.

5. Payne CE, Stein JM, Leong T, and Dressler DD. Avoiding Handover Fumbles: A Controlled Trial of $A$ Structured Handover Tool versus Traditional Handover Methods. BMJ Quality \& Safety. 2012; yang menggambarkan suasana internal UGD dan eksternal UGD. Hal ini sesuai dengan hasil penelitian yang dilakukan oleh Farhan yang menyususn $A B C$ handover yang menyebutkan bahwa hal-hal yang harus disampaikan pada saat timbang terima adalah sebagai berikut:kondisi internal UGD (jumlah pasien di UGD, jumlah tempat tidur kosong di UGD, dan kondisi peralatan di UGD) dan kondisi eksternal UGD (7).

\section{1(11): 925-932.}

6. Manser $\mathrm{T}$ and Foster S. Effective Handover Communication: An overview of Research and Improvement Efforts. Best Practice \& Research Clinical Anaesthesiology. 2011; 25(2): 181-191.

7. Farhan $\mathrm{M}$, Brown $\mathrm{R}$, Woloshynowych $\mathrm{M}$, and Vincent C. The $A B C$ of Handover: A Qualitative Study to Develop a New Tool for Handover in the Emergency Department. Emergency Medicine Journal. 2012; 29(12):941-946.

8. Lasswell HD. The Structure and Function of Communication in Society. Iletişim Kuram ve Araştırma Dergisi.2007; 24: 215-228.

9. Ye K, McD Taylor D, Knott JC, Dent A, and MacBean CE. Handover in the Emergency Department: Deficiencies and Adverse Effects. Emergency Medicine Australasia. 2007; 19(5):433-441.

10. Bendaly L BN. Improving Healthcare Team Performance. Ontario: John Wiley \& Sons Canada,Ltd; 2012. 